\title{
Analisis Aplikasi Akad Tabarru' dalam Asuransi Syariah: Studi Kasus pada AJB Bumiputera 1912 Syariah Cabang Kudus
}

\author{
M. Arif Hakim \\ Sekolah Tinggi Agama Islam Negeri (STAIN) Kudus \\ arif_stainkds@yahoo.com
}

\begin{abstract}
:
The purpose of this research is to (1) know of products of Islamic insurance at AJB Bumiputera 1912 Syariah Cabang Kudus; (2) know how procedure and mechanism of application of akad tabarru' in Islamic insurance at AJB Bumiputera 1912 Syariah Cabang Kudus; (3) analyse the application of akad tabarru' in Islamic insurance at AJB Bumiputera 1912 Syariah Cabang Kudus.This research including field research with qualitative approach. Data analysis using descriptive analysis. Result of this research indicate that (1) products at AJB Bumiputera 1912 Syariah Cabang Kudus are products with saving system; individual insurance (Mitra Sakinah, Mitra Mabrur and Mitra Iqra') and group insurance; (2) in executing daily activity of AJB Bumiputera 1912 Syariah Cabang Kudus, premium which step into the company grouped to become the Tabarru' (benefaction fund), Premium of Saving and Premium of Cost; (3) application of Akad tabarru' at AJB Bumiputera 1912 Syariah Cabang Kudus as according to religious advices of Dewan Syariah NasionalMajelis Ulama Indonesia (DSN-MUI) No. 21/DSN-MUI/X/2001 about common guidance of islamic insurance expressed that akad tabarru' is all form akad done with benefaction purpose and help mutually, not for the commercial purpose.
\end{abstract}

Keywords: Application, Tabarru', Islamic insurance.

\section{Abstrak:}

Tujuan penelitian ini adalah untuk: (1) mengetahui produk-produk asuransi syariah pada AJB Bumiputera 1912 Syariah Cabang Kudus; (2) mengetahui prosedur dan mekanisme pelaksanaan akad tabarru' dalam asuransi syariah yang ada di AJB Bumiputera 1912 Syariah cabang Kudus; (3) menganalisis prosedur dan mekanisme pelaksanaan akad tabarru' yang ada di AJB 
Bumiputera 1912 Syariah cabang Kudus. Penelitian ini termasuk penelitian lapangan (field reserarch) dengan menggunakan metode kualitatif. Analisis data menggunakan descriptive analysis. Hasil penelitian ini menunjukkan bahwa (1) produk-produk pada AJB Bumiputera 1912 syariah cabang Kudus adalah termasuk produk yang ada unsur saving (tabungan), yaitu asuransi perorangan (Mitra Sakinah, Mitra Mabrur dan Mitra Iqra') maupun asuransi kumpulan; (2) dalam melaksanakan kegiatan harian AJB Bumiputera 1912 syariah cabang Kudus, premi yang masuk ke perusahaan dikelompokkan menjadi premi Tabarru' (dana kebajikan), Premi Tabungan dan Premi Biaya; (3) Aplikasi akad tabarru' pada AJB Bumiputera 1912 Syariah Cabang Kudus sesuai dengan fatwa Dewan Syariah Nasional (DSN) Nomor 21/DSN-MUI/ $\mathrm{X} / 2001$ tentang pedoman umum asuransi syariah dinyatakan bahwa akad tabarru' adalah semua bentuk akad yang dilakukan dengan tujuan kebajikan dan tolong-menolong, bukan semata untuk tujuan komersial.

Kata Kunci: Aplikasi, Tabarru', Asuransi Syariah.

\section{Pendahuluan}

Dalam praktek asuransi konvensional disinyalir terdapat unsur-unsur yang bertentangan dengan syariah Islam, seperti maisir, garar, riba, dzalim dan sebagainya. Secara spesifik ada tiga unsur pokok dalam asuransi yang dipandang bertentangan dengan nilai-nilai syariah yaitu bahaya yang dipertanggungkan, premi pertanggungan dan sejumlah uang ganti rugi pertanggungan.

Untuk mencari jalan keluar dari berbagai macam unsur yang dipandang tidak sejalan dengan syariah, telah diusahakan adanya perusahaan asuransi yang menekankan sifat saling menanggung, saling menolong di antara para tertanggung yang bernilai kebajikan menurut ajaran Islam (Basyir dalam Sudarsono, 2004: 113-114).

Kajian asuransi syariah dalam hukum Islam merupakan hal yang baru, dan belum pernah ditemukan dalam literatur fiqh klasik. Pembahasan asuransi dalam wilayah kajian ilmu-ilmu ke-Islaman baru muncul pada fase lahirnya ulama kontemporer. Di sisi lain, kajian tentang asuransi merupakan sebuah paket dari kajian ekonomi Islam yang biasanya selalu dikaji bersama-sama dengan pembahasan perbankan dalam Islam. 
Secara prinsipil kajian ekonomi Islam selalu mengedepankan asas keadilan, tolong menolong, menghindari kedzaliman, pengharaman riba (bunga), prinsip profit and loss sharing serta penghilangan unsur garar. Di samping itu, lembaga asuransi syariah perlu mengembangkan sebuah manajemen asuransi secara mandiri, terpadu dan profesional serta tidak menyalahi aturan dasar yang telah digariskan dalam ajaran syariah Islam.

Di sinilah ulama kontemporer berperan dalam menggali dan menyusun sebuah kinerja lembaga asuransi syariah yang memasukkan unsur tolong-menolong, seperti yang terjadi di awal sejarah asuransi yang menjadikan tolong-menolong sebagai unsur utama di dalamnya. Dari sini, asuransi syariah mengemban tugas membersihkan unsur-unsur yang tidak sesuai dengan syariah terhadap praktik yang dijalankan oleh asuransi konvensional.

Saat ini, Indonesia dikenal sebagai salah satu negara dengan jumlah operator asuransi syariah cukup banyak di dunia. Berdasarkan data Dewan Syariah Nasional-Majelis Ulama Indonesia (www.republika.co.id), terdapat 49 pemain asuransi syariah di Indonesia yang telah mendapatkan rekomendasi syariah. Mereka terdiri dari 40 operator asuransi syariah, tiga reasuransi syariah dan enam broker asuransi dan reasuransi syariah.

Perkembangan industri asuransi syariah di negeri ini diawali dengan kelahiran asuransi syariah pertama Indonesia pada 1994. Saat itu, PT. Syarikat Takaful Indonesia (STI) berdiri pada 24 Februari 1994 yang dimotori oleh ICMI melalui Yayasan Abdi Bangsa, Bank Muamalat Indonesia, PT. Asuransi Jiwa Tugu Mandiri, Departemen Keuangan RI, serta beberapa pengusaha Muslim Indonesia.

Selanjutnya, STI mendirikan dua anak perusahaan, yaitu perusahaan asuransi jiwa syariah bernama PT. Asuransi Takaful Keluarga (ATK) pada 4 Agustus 1994 dan perusahaan asuransi kerugian syariah bernama PT. Asuransi Takaful Umum (ATU) pada 2 Juni 1995. Setelah Asuransi Takaful dibuka, berbagai perusahaan asuransi pun menyadari cukup besarnya potensi bisnis asuransi syariah di Indonesia. Hal tersebut kemudian mendorong berbagai perusahaan ramai-ramai masuk bisnis asuransi syariah, di antaranya dilakukan dengan langsung mendirikan perusahaan asuransi syariah penuh maupun membuka divisi atau cabang asuransi syariah. 
Strategi pengembangan bisnis asuransi syariah melalui pendirian perusahaan dilakukan oleh Asuransi Syariah Mubarakah yang bergerak pada bisnis asuransi jiwa syariah. Sedangkan strategi pengembangan bisnis melalui pembukaan divisi atau cabang asuransi syariah dilakukan sebagian besar perusahaan asuransi, antara lain PT. MAA Life Assurance, PT. MAA General Assurance, PT. Great Eastern Life Indonesia, PT. Asuransi Tri Pakarta, PT. AJB Bumiputera 1912 dan PT. Asuransi Jiwa BRIngin Life Sejahtera.

Bahkan, sejumlah pemain asuransi besar dunia pun turut tertarik masuk dalam bisnis asuransi syariah di Indonesia. Mereka menilai Indonesia sebagai negara berpenduduk Muslim terbesar di dunia merupakan potensi pengembangan bisnis cukup besar yang tidak dapat diabaikan. Di antara perusahaan asuransi global yang masuk dalam bisnis asuransi syariah Indonesia adalah PT. Asuransi Allianz Life Indonesia dan PT. Prudential Life Assurance.

Dalam mu'amalah, kejelasan bentuk akad (www.tazkiaonline.com) sangat menentukan apakah transaksi yang dilakukan sudah sah atau tidak menurut kaidah syar'i. Demikian pula dalam berasuransi, ketidakjelasan bentuk akad akan berpotensi menimbulkan permasalahan dari sisi legalitas hukum Islam. Karena asuransi pada mulanya tidak dikenal dalam literatur Islam maka oleh jumhur ulama di-qiyas-kan sebagai praktek jual-beli. Dengan demikian, sah tidaknya transaksi asuransi dari kacamata syariah ditentukan oleh terpenuhi atau tidaknya rukun jual-beli (Rambe, 1994).

Dalam fatwa Dewan Syariah Nasional (DSN) Nomor 21/DSN-MUI/ $\mathrm{X} / 2001$ tentang pedoman umum asuransi syariah dinyatakan bahwa asuransi syariah (ta'mīn, takāful atau tậāmun) adalah usaha saling melindungi dan tolong menolong di antara sejumlah orang atau pihak melalui investasi dalam bentuk aset dan atau tabarru' yang memberikan pola pengembalian untuk menghadapi risiko tertentu melalui akad (perikatan) yang sesuai dengan syariah (tidak mengandung unsur garar atau penipuan, maisir atau perjudian, riba, zulm atau penganiayaan, rishwah atau suap, barang haram dan maksiat). Yang dimaksud akad tijārah adalah semua bentuk akad yang dilakukan untuk tujuan komersial. Sedangkan akad tabarru' adalah semua bentuk akad yang dilakukan dengan tujuan kebajikan dan tolong-menolong, bukan semata untuk tujuan komersial. 
Implementasi akad tabarru' dalam sistem asuransi syariah direalisasikan dalam bentuk pembagian setoran premi menjadi dua. Untuk produk yang mengandung unsur tabungan (saving), maka premi yang dibayarkan akan dibagi ke dalam rekening dana peserta dan satunya lagi rekening tabarru'. Sedangkan untuk produk yang tidak mengandung unsur tabungan (non-saving), setiap premi yang dibayar akan dimasukkan seluruhnya ke dalam rekening tabarru'. Keberadaan rekening tabarru' menjadi sangat penting untuk menjawab pertanyaan seputar ketidakjelasan (ke-gararan) asuransi dari sisi pembayaran klaim.

AJB Bumiputera 1912 Syariah yang merupakan perusahaan asuransi jiwa tertua dan terbesar di Indonesia juga meluncurkan program baru, antara lain marketing tag baru "Bila syariah juga ada di Bumiputera, mengapa pilih yang lain?". Bukti keseriusan Bumiputera antara lain ditandai dengan pembukaan 7 kantor wilayah yang membawahi 46 kantor cabang yang tersebar di 46 kota di Indonesia.

Oleh karena begitu urgen dan vitalnya akad tabarru' dalam asuransi syariah, maka penelitian ini berusaha akan melakukan kajian dan analisis tentang aplikasi atau penerapan akad tabarru' pada AJB Bumiputera 1912 syariah cabang Kudus.

\section{Rumusan Masalah}

Secara ringkas, rumusan masalah dalam penelitian ini tentang apa saja produk-produk asuransi syariah pada AJB Bumiputera 1912 Syariah Cabang Kudus. Lalu bagaimana prosedur dan mekanisme pelaksanaan akad tabarru' dalam asuransi syariah yang ada di AJB Bumiputera 1912 Syariah cabang Kudus. Dan terakhir, apakah prosedur dan mekanisme pelaksanaan akad tabarru' yang ada di AJB Bumiputera 1912 Syariah cabang Kudus telah sesuai dengan prinsip-prinsip syariah.

\section{Penelitian Sebelumnya}

Freddy Pasaribu (2004) telah meneliti tentang "Perbandingan Perhitungan Premi Asuransi Beasiswa Berencana AJB Bumiputera 1912 
Kantor Operasional Gambir dan AIA Education PT. Asuransi AIA Indonesia”. Ia menyimpulkan bahwa premi yang ditetapkan oleh AJB Bumiputera 1912 lebih ringan karena masa pembayaran preminya lebih lama. Sedangkan dari pihak PT. Asuransi AIA Indonesia pembayaran preminya sedikit lebih besar dikarenakan masa pembayaran premi lebih singkat.

Kemudian penelitian yang dilakukan oleh Ikrom bin Abdul Rahman (2005), yang meneliti tentang “Asas-Asas Perlindungan Nasabah Tertanggung menurut Asuransi Takaful Syariah dan Pelaksanaannya pada PT. Asuransi Takaful Syariah Medan”. Hasilnya menunjukkan bahwa asasasas perlindungan terhadap nasabah tertanggung dalam Asuransi Takaful yaitu asas saling bertanggung jawab, saling membantu dan saling melindungi antar sesama nasabah. Pihak Asuransi Takaful menjamin pelaksanaan asasasas tersebut dijalankan secara baik sesuai dengan konsep syariah Islam.

Kemudian ada lagi penelitian berjudul "Asas Perlindungan Hukum terhadap Nasabah dalam Asuransi Syariah (Studi Kasus Asuransi Takaful Keluarga Cabang Medan)" yang dilakukan oleh Zulfajri (2006). Ia menyimpulkan bahwa bentuk penerapan asas-asas syariah yang berhubungan dengan asas perlindungan hukum terhadap nasabah dalam asuransi syariah pada umumnya dan Asuransi Takaful pada khususnya, adalah dari perjanjian atau polis asuransi dan syarat umum polis yang dikeluarkan oleh Asuransi Takaful Keluarga sendiri. Aturan syariah tersebut dapat mengikat kepada pihak dan nasabah mendapat perlindungan hukum.

Nurwati Indah Murni melakukan penelitian dengan judul "Tinjauan Yuridis Pelaksanaan Asuransi Takaful Berdasarkan Fatwa Dewan Syariah Nasional Nomor: 21/DSN-MUI/X/2001 Tentang Pedoman Umum Asuransi Syariah". Dengan memakai pendekatan yuridis normatif, dia menyimpulkan bahwa keabsahan akad yang mendasari kontrak asuransi syariah didasarkan pada al-Qur'an, Sunnah, Qiyas dan Ijma'. Oleh karenanya, dalam hal ini umat Islam tidak perlu ragu terhadap produk asuransi syariah, karena akad yang diterapkan dalam asuransi syariah merupakan akad yang memang bertujuan untuk menghindari hal-hal yang dilarang oleh agama Islam seperti garar, maisir, dan riba.

Penelitian tentang "Prediksi Tingkat Kesehatan Perusahaan Asuransi Jiwa Termasuk Kemungkinan Kebangkrutannya dengan Rasio-Rasio 
Keuangan” telah dilakukan oleh Peni Sawitri. Data sekunder berupa hasil peringkat Asuransi Jiwa yang telah dilakukan Biro Riset Infobank per Desember 2000 terhadap 60 perusahaan asuransi jiwa digunakan dalam analisis. Analisis dilakukan menggunakan metode multiple discriminant analysis (MDA) yaitu model dari fungsi diskriminan atau disebut dengan linear discriminant function terhadap rasio-rasio versi Biro Riset Infobank tersebut. Semua kriteria rasio yang dipilih oleh Biro Riset InfoBank masih belum dapat dijadikan estimator atau penentu ukuran kesehatan perusahaan asuransi jiwa karena hanya 44,9\% saja ketepatannya, jadi masih banyak variabel lain yang sebenarnya menjadi ukuran kesehatan perusahaan asuransi jiwa.

Noor A'izah dalam penelitiaannya tentang "Pengaruh Strategi Diferensiasi dan Positioning Produk terhadap Persepsi dan Motivasi Konsumen dalam Mengambil Polis Asuransi Mitra Iqra' di Asuransi Jiwa Syari'ah Bumiputera 1912 Cabang Kudus" menyimpulkan bahwa hasil analisis SEM menunjukkan bahwa strategi diferensiasi berpengaruh terhadap persepsi konsumen, karena nilai $\mathrm{CR}^{-}+1,96$, tingkat signifikansi $5 \%$, dan standardized regression weight sebesar 0,006 . Kemudian positioning produk berpengaruh terhadap persepsi konsumen, bisa dilihat nilai $\mathrm{CR}^{-}+1,96$, tingkat signifikansi $5 \%$, dan standardized regression weight 3,329. Sedangkan persepsi konsumen berpengaruh terhadap motivasi konsumen, karena nilai $\mathrm{CR}^{-}+1,96$, tingkat signifikansi $5 \%$, dan standardized regression weight sebesar 0,497 .

Salamun meneliti tentang "Analisis tentang Regulasi Asuransi Syariah AJB Bumiputera Cabang Kudus Tahun 2007" dengan hasil bahwa regulasi produk Asuransi Syariah Bumiputera Cabang Kudus Tahun 2007 berdasarkan pada fatwa Dewan Syariah Nasional MUI tentang pedoman umum asuransi syariah. Asuransi syariah yang ditawarkan AJB Bumiputera termasuk kategori asuransi yang diperbolehkan oleh sebagian ulama.

Menurut hemat penulis, belum ada penelitian tentang aplikasi akad tabarru' pada AJB Bumiputera 1912 divisi syariah cabang Kudus. 


\section{Akad Tabarru'}

Kata akad berasal dari kata al-'aqd, yang berarti mengikat, menyambung atau menghubungkan (al-rabt). Menurut Syamsul Anwar (2007: 68), akad adalah pertemuan ijab dan kabul sebagai pernyataan kehendak dua pihak atau lebih untuk melahirkan suatu akibat hukum pada objeknya.

Dalam hukum Islam, untuk terbentuknya suatu akad yang sah dan mengikat haruslah dipenuhi rukun akad dan syarat akad (Anwar, 2007: 95105). Syarat akad dibedakan menjadi empat macam, yaitu syarat terbentuknya akad (shurūt al-in'iqād), syarat keabsahan akad (shurūt alsiḥhah), syarat berlakunya akibat hukum akad (shurüt al-nafädh) dan syarat mengikatnya akad (shurūt al-luzūm). Sedangkan rukun akad ada empat, yaitu para pihak yang membuat akad (al-'āqidain), pernyataan kehendak para pihak (ṣigàt al-'aqd), objek akad (maḥal al-'aqd) dan tujuan akad (maudu' al-'aqd).

Dari segi ada atau tidaknya kompensasi, akad terbagi menjadi dua bagian, yaitu akad tabarru' (gratuitous contract) dan akad tijārah (compensatinal contract).

\section{Definisi Asuransi Syariah}

Dalam literatur hukum Islam, asuransi dikenal dengan sebutan altakāful, al-taḍāmun dan al-ta'mīn.

Dalam fatwa Dewan Syariah Nasional (DSN) Nomor 21/DSN-MUI/ $\mathrm{X} / 2001$ tentang pedoman umum asuransi syariah dinyatakan bahwa asuransi syariah (ta'mīn, takāful atau tậāmun) adalah usaha saling melindungi dan tolong menolong di antara sejumlah orang/pihak melalui investasi dalam bentuk aset dan atau tabarru' yang memberikan pola pengembalian untuk menghadapi risiko tertentu melalui akad (perikatan) yang sesuai dengan syariah (tidak mengandung unsur garar atau penipuan, maisir atau perjudian, riba, zulm atau penganiayaan, rishwah atau suap, barang haram dan maksiat). 


\section{Prinsip Dasar dan Syarat Utama dalam Asuransi Syariah}

Prinsip dasar yang ada dalam asuransi syariah tidaklah jauh berbeda dengan prinsip dasar yang berlaku pada ekonomi Islam secara komprehensif. Hal ini disebabkan karena kajian asuransi syariah merupakan turunan dari konsep ekonomi Islam.

Prinsip-prinsip dasar dalam asuransi syariah (Sudarsono, 2004: 115116; Ali, 2004: 125-136) adalah tauhid (unity), keadilan (justice), tolongmenolong (ta'āwun), kerja sama (cooperation), amanah (trustworthy atau al-amānah), kerelaan (al-rị̣a), larangan riba, larangan maisir (judi), larangan ketidakpastian (garar) dan larangan haram dan maksiat.

Di samping itu, asuransi syariah harus memiliki persyaratan utama agar bisa beroperasi secara Islami, yaitu syarat-syarat produk, syarat-syarat bermitra, syarat-syarat investasi, syarat-syarat manajemen serta syarat-syarat akutansi yang harus sesuai dengan syariah.

\section{Mengeliminir Garar, Maisir dan Riba dalam Akad Asuransi Syariah}

Sebagaimana diketahui bahwa akad merupakan salah satu persoalan pokok dalam asuransi konvensional yang menjadikannya diharamkan oleh para ulama. Selama ini akad yang ada di asuransi konvensional, dapat berdampak pada munculnya garar dan maisir. Oleh karena itu, para ulama mencarai solusi bagaimana agar masalah garar, maisir dan riba dapat dihindarkan (Sula, 2004: 174-176).

\section{Masalah Garar}

Masalah garar (penipuan) muncul karena akad yang dipakai dalam asuransi konvensional adalah akad tabāduli (akad pertukaran; jual-beli). Dalam asuransi syariah, masalah garar ini dapat diatasi dengan mengganti akad tabāduli dengan akad takāfuli (saling menanggung; tolongmenolong) atau akad tabarru' dan akad muḍārabah (bagi hasil).

\section{Masalah Maisir}

Sebagaimana diketahui bahwa maisir adalah adanya salah satu pihak 
yang untung namun di lain pihak justru mengalami kerugian. Dalam asuransi syariah, reversing period bermula dari awal akad di mana setiap peserta mempunyai hak untuk mendapatkan cash value, kapan saja, dan mendapatkan semua uang yang telah dibayarkannya kecuali sebagian kecil saja. Yaitu, yang telah diniatkan untuk dana tabarru' yang sudah dimasukkan ke dalam rekening khusus peserta dalam bentuk tabarru' atau dana kebajikan.

\section{Masalah Riba}

Pada asuransi syariah, masalah riba (bunga) dieliminir dengan konsep muḍārabah (bagi hasil). Seluruh bagian dari proses operasional asuransi yang di dalamnya menganut sistem riba, digantikannya dengan akad muḍ̄ărabah atau akad lainnya (Iqbal, 2005: 28-29) yang dibenarkan secara syar'i.

\section{Landasan Akad dalam Asuransi Syariah}

\section{Al-Ta'āwun}

Al-ta'āwun merupakan salah satu prinsip yang menjadi landasan etika dalam mu'amalah yang Islami. Tak dapat diragukan dengan dalil-dalil yang kuat baik dalam al-Qur'an dan hadits, maka ta'āwun merupakan salah satu prinsip utama dalam interaksi mu'amalah. Bahkan, ta'āwun dapat menjadi fondasi dalam membangun sistem ekonomi yang kokoh, agar pihak yang kuat membantu yang lemah, masyarakat yang kaya memperhatikan yang miskin dan seterusnya. Ta'āwun merupakan inti dari konsep takāful, di mana antara satu peserta dengan peserta lainnya saling menanggung risiko melalui mekanisme dana tabarru' dengan akad yang benar yaitu akad takāfuli atau akad tabarru'.

\section{Akad al-Tabarru'}

Akad tabarru' adalah semua bentuk akad yang dilakukan dengan tujuan kebaikan dan tolong-menolong, bukan semata untuk tujuan komersial. Dalam akad tabarru' hibah, peserta memberikan hibah yang akan digunakan untuk menolong peserta lain yang terkena musibah, sedangkan perusahaan 
hanya bertindak sebagai pengelola.

\section{Akad Takāful}

Dalam pengertian mu'amalah, takāful mengandung arti saling memikul risiko di antara sesama peserta, sehingga antara satu dengan lainnya menjadi penanggung atas risiko yang lainnya, dan ini dilakukan atas dasar saling tolong-menolong dalam kebaikan dan ketakwaan (wa ta'āwanu 'ala al-birr wa al-taqwa) dengan cara masing-masing mengeluarkan dana tabarru' yang ditujukan untuk menanggung risiko.

Implementasi akad takāful dan tabarru' dalam sistem asuransi syariah direalisasikan dalam bentuk pembagian setoran premi menjadi dua. Untuk produk yang mengandung unsur tabungan (saving), maka premi yang dibayarkan akan dibagi ke dalam rekening dana peserta dan rekening tabarru'. Sedangkan untuk produk yang tidak mengandung unsur tabungan (non-saving), setiap premi yang dibayar akan dimasukkan seluruhnya ke dalam rekening tabarru'.

\section{Implementasi Akad Tijārah dalam Asuransi Syariah}

\section{Akad al-Muḍārabah}

Secara teknis, muḍārabah (Syafi'i Antonio, 2001: 95) didefinisikan sebagai akad kerja sama antara dua pihak di mana pihak pertama (șāhib almāl) menyediakan $100 \%$ modal sedangkan pihak lainnya menjadi pengelola (al-muḍārib). Apabila dalam usahanya diperoleh keuntungan (profit) maka keuntungan tadi dibagi antara șạhib al-māl dan al-muḍārib dengan prosentase nisbah atau rasio yang telah disepakati sejak awal perjanjian atau kontrak. Sedangkan apabila usaha tersebut merugi maka kerugian tersebut akan ditanggung sepenuhnya oleh pihak șăḥib al-māl sepanjang hal itu disebabkan oleh risiko bisnis dan bukan karena kelalaian muḍārib.

Jenis Muḍārabah terbagi kepada dua (Antonio, 2001: 97), yaitu: (1) Muḍ̄ārabah Muṭlaqah; dan (2) Muḍ̄āabah Muqayyadah.

Adapun penerapan akad muḍārabah dalam bisnis asuransi syariah dapat dilihat dalam 2 bidang usaha asuransi (www.pojokasuransi.com) yaitu asuransi jiwa (life insurance) dan asuransi kerugian (general insurance). 
Perbedaan karakteristik bisnis antara kedua jenis usaha tersebut menyebabkan penerapan akad muḍārabah menjadi berbeda meskipun secara prinsip tetap mengikuti kaidah konsep muḍārabah di mana para peserta asuransi berkedudukan sebagai șăḥib al-māl (pemilik modal) dan perusahaan bertindak sebagai muḍārib (pengelola).

\section{Akad al-Mushạrakah}

Mushạrakah (Wahbah az-Zuhaili, 1409 H, IV: 794) ialah perjanjian (akad) antara kedua belah pihak atau lebih dalam suatu usaha tertentu. Masing-masing pihak akan memberikan kontribusi dengan kesepakatan jika terdapat keuntungan atau kerugian, masing-masing pihak mendapat margin dan menanggung risiko.

Filosofi transaksi mushạrakah dilandasi dengan adanya keinginan para pihak yang ingin bekerjasama untuk meningkatkan nilai aset yang mereka miliki secara bersama-sama (Karim, 2007: 90). Yakni semua bentuk usaha yang melibatkan dua pihak atau lebih di mana mereka secara bersama-sama memadukan seluruh sumber daya, baik yang berwujud maupun yang tidak berwujud.

Dalam praktek asuransi syariah, pada hakikatnya bentuk kerjasama di lembaga asuransi ini adalah bentuk kerjasama yang dilandasi oleh prinsip al-mushạrakah, di mana ada pihak yang punya dana dan modal, dan ada pihak lain yang hanya memiliki tenaga dan skill serta profesionalisme.

\section{Akad al-Wakālah}

Wakālah atau wikālah (Antonio, 2001: 120) berarti penyerahan, pendelegasian atau pemberian mandat. Dalam bahasa Arab hal ini dapat dipahami sebagai al-tafwị̀. Pengertian yang sama dengan menggunakan kata al-hifẓu.

Jadi, wakālah merupakan pelimpahan, pendelegasian wewenang atau kuasa dari pihak pertama kepada pihak kedua untuk melaksanakan sesuatu atas nama pihak pertama dan untuk kepentingan dan tanggung jawab sepenuhnya oleh pihak pertama. Dalam hal ini, pihak kedua hanya melaksanakan sesuatu sebatas kuasa atau wewenang yang diberikan oleh pihak pertama. Namun apabila kuasa itu telah dilaksanakan sesuai dengan yang disyaratkan, 
maka semua risiko dan tanggung jawab atas dilaksanakannya perintah tersebut sepenuhnya menjadi tanggung jawab pihak pertama atau pemberi kuasa.

Pada prakteknya akad al-wakālah banyak dipakai dalam asuransi syariah. Pemasaran (marketing) adalah manifestasi bentuk akad wakālah dalam asuransi syariah.

\section{Akad al-Wadi' 'ah}

Pengertian al-wadi' 'ah (Haroen, 2000: 244) secara bahasa berarti meninggalkan atau meletakkan, yaitu meletakkan sesuatu pada orang lain untuk dipelihara atau dijaga. Sedangkan secara istilah, al-wadi' $a h$ adalah memberikan kekuasaan kepada orang lain untuk menjaga hartanya atau barangnya dengan secara terang-terangan atau dengan isyarat yang semakna dengan itu.

Dalam praktik asuransi syariah, prinsip wadi' ah yang diterapkan adalah wadi' $a h$ yad d̦amānah yang diterapkan pada produk rekening giro. Wadi' ah ḍamānah berbeda dengan wadi' ah amānah. Dalam wadi'ah amānah, pada dasarnya harta titipan tidak boleh dimanfaatkan oleh yang dititip. Sedangkan dalam wadi' ah ḍamānah, pihak yang dititipi (bank atau asuransi) bertanggung jawab atas keutuhan harta titipan sehingga ia boleh memanfaatkan harta titipan tersebut (Karim, 2007: 96).

\section{Metode Penelitian}

Metode penelitian yang digunakan dalam penelitian ini adalah metode kualitatif. Metode kualitatif ini muncul karena terjadi perubahan paradigma dalam memandang suatu realitas (fenomena atau gejala). Metode kualitatif (Sugiyono, 2004: 95) adalah metode penelitian yang digunakan untuk meneliti pada kondisi obyek alamiah, di mana peneliti adalah sebagai instrumen kunci, teknik pengumpulan data dilakukan bersifat induktif dan hasil penelitian kualitatif lebih menekankan makna generalisasi.

Dalam penelitian kualitatif, peneliti mendapatkan data dari hasil wawancara, dari hasil observasi atau dari sejumlah dokumen (Faisal, 2003: 62). Muara dari seluruh kegiatan analisis data kualitatif adalah terletak pada 
pelukisan atau penuturan tentang apa yang berhasil kita mengerti berkenaan dengan sesuatu masalah yang diteliti.

Data yang digunakan dalam penelitian ini adalah jenis data primer dan sekunder. Metode yang digunakan peneliti untuk memperoleh data adalah dengan metode wawancara, observasi dan dokumentasi (Teguh, 2005: $60)$.

Dalam penelitian kualitatif, analisis data lebih ditekankan selama proses di lapangan bersamaan dengan pengumpulan data. Analisis data merupakan proses mencari dan menyusun secara sistematis data yang diperoleh dari hasil wawancara, observasi dan dokumentasi dengan cara mengorganisasikan data ke dalam kategori, menjabarkan ke dalam unit-unit, melakukan sintesa, menyusun ke dalam pola, memilih mana yang penting dan yang akan dipelajari dan membuat kesimpulan sehingga mudah dipahami oleh diri sendiri dan orang lain. Analisis data kualitatif bersifat induktif, yaitu dari hasil penelitian yang bersifat umum akan disimpulkan menjadi khusus (Hamidi, 2004: 70).

\section{Produk-produk AJB Bumiputera 1912 Syariah Cabang Kudus}

Ada empat produk asuransi syariah di AJB Bumiputera 1921 Cabang Kudus, yaitu:

a. Mitra Sakinah; Produk asuransi ini membantu peserta dalam merencanakan dana tabungan untuk hari tua atau untuk keperluan lainnya sejak dini dengan menyisihkan sebagian pendapatan secara teratur, dan juga sebagai perlindungan bagi orang-orang ang dicintai sekiranya terjadi sesuatu yang tidak dikehendaki.

b. Mitra Mabrur; Produk asuransi ini membantu peserta dalam merencanakan dana tabungan untuk pergi haji, umroh atau untuk keperluan lainnya sejak dini dengan menyisihkan sebagian pendapatan secara teratur dan juga sebagai perlindungan untuk orang-orang yang dicintai sekiranya terjadi sesuatu yang tidak dikehendaki.

c. Mitra Iqra'; Produk Mitra Iqra' akan membantu dalam merencanakan dana tabungan pendidikan bagi putra-putri peserta sejak dini dengan menyisihkan sebagian pendapatan secara teratur, dan juga sebagai 
perlindungan bagi putra-putri peserta sekiranya terjadi sesuatu yang tidak dikehendaki. Dengan demikian, peserta tidak perlu khawatir pendidikan putra-putrinya berhenti di tengah jalan.

d. Askum Syariah; Yaitu bentuk perlindungan dari perusahaan asuransi syariah kepada sejumlah umat Islam dalam suatu perusahaan atau lembaga yang saling berderma dalam kebajikan dan memberikan profit sharing jika pada akhir akad terjadi surplus operasional.

\section{Mekanisme Pengelolaan Premi pada AJB Bumiputera 1912 Syariah Kudus}

Dalam melaksanakan kegiatan harian AJB Bumiputera 1912 syariah cabang Kudus bahwa premi yang masuk ke perusahaan dikelompokkan menjadi:

a. Tabarru' (dana kebajikan)

Tabarru' berasal dari kata tabarra'a-yatabarra'u-tabarru'an, artinya sumbangan atau dana kebajikan atau derma. Orang yang memberi sumbangan disebut mutabarri' (dermawan). Niat tabarru' adalah alternatif yang sah yang dibenarkan oleh syara' dalam melepaskan diri dari praktek garar yang diharamkan dalam praktik asuransi konvensional. Premi tabarru' merupakan bagian premi yang diikhlaskan, disumbangkan untuk tujuan tolong-menolong kepada sesama peserta asuransi.

b. Premi Tabungan

Premi tabungan adalah bagian premi yang merupakan tabungan para peserta yang mutlak menjadi milik para peserta asuransi. Premi tabungan ini dapat diambil kapan saja oleh peserta asuransi, atau dikembalikan pada akhir kontrak asuransi. Premi tabungan ini mendapatkan bagi hasil (muḍārabah).

c. Premi Biaya

Premi biaya adalah bagian premi yang diserahkan kepada perusahaan asuransi sebagai biaya pengelolaan. Premi biaya pada sebagian perusahaan asuransi syariah dibebankan kepada peserta asuransi, sebagian yang lainnya tidak membebankan biaya pengelolaan tersebut. 
Besarnya premi untuk masing-masing peserta dihitung atas dasar usia debitur atau peminjam, jangka waktu asuransi, besar pembiayaan atau pinjaman awal, premi dibayar secara sekaligus atau tunggal dan dibayar di muka pada saat akad pembiayaan ditandatangani dan besarnya sesuai tabel premi.

Kumpulan dana peserta ini diinvestasikan sesuai dengan syariah Islam dan tiap keuntungan dari hasil investasi setelah dikurangi beban asuransi (klaim dan premi reasuransi), akan dibagi dengan prinsip muḍārabah.

\section{Pembahasan}

\section{Produk-produk AJB Bumiputera 1912 Syariah Cabang Kudus}

Sebelum kita menganalisis produk-produk yang ditawarkan oleh AJB Bumiputera 1912 Syariah Cabang Kudus baik dalam bentuk asuransi perorangan (Mitra Sakinah, Mitra Mabrur dan Mitra Iqra') maupun asuransi kumpulan, maka alangkah baiknya kita mengetahui terlebih dahulu dua macam produk asuransi syariah.

Adapun produk asuransi syariah yang sering dipakai dalam operasional sebuah perusahaan asuransi syariah secara garis besar dapat dipilah menjadi dua, yaitu (a) produk asuransi syariah dengan unsur saving, dan (b) produk asuransi syariah non-saving (Hasan Ali, 2004:168-170).

Berdasarkan dua bentuk produk di atas beserta skema mekanisme pengelolaannya, maka dapat diambil kesimpulan bahwa produk-produk yang ditawarkan oleh AJB Bumiputera 1912 syariah cabang Kudus adalah termasuk produk asuransi syariah yang ada unsur saving (tabungan). Karena selain ada rekening atau premi tabarru' yang notabene merupakan akad yang mendasari asuransi syariah, peserta juga harus membayar rekening atau premi tabungan. Jadi, dalam hal ini pihak pengelola AJB Bumiputera 1912 syariah cabang Kudus ingin mengajak masyarakat untuk berasuransi sambil berinvestasi sekaligus.

\section{Mekanisme Pengelolaan Premi pada AJB Bumiputera 1912 Syariah Cabang Kudus}

Mekanisme pengelolaan dana peserta (premi) terbagi menjadi dua sistem, yaitu (Syakir Sula, 2004: 177-179): (a) Sistem pada produk saving 
(tabungan); (b) Sistem pada produk non-saving (tanpa tabungan).

Dalam sistem pada produk saving (tabungan), peserta wajib membayar sejumlah uang (premi) secara teratur kepada perusahaan. Besar premi yang dibayarkan tergantung kepada keuangan peserta. Akan tetapi, perusahaan menetapkan jumlah minimum premi yang akan dibayarkan. Setiap premi yang dibayarkan oleh peserta, akan dipisah dalam dua rekening yang berbeda: (1) Rekening tabungan peserta, yaitu dana yang merupakan milik peserta, yang dibayarkan bila perjanjian berakhir, atau peserta mengundurkan diri, atau peserta meninggal dunia; (2) Rekening Tabarru', yaitu kumpulan dana kebajikan yang telah diniatkan oleh peserta sebagai iuran dana kebajikan untuk tujuan saling menolong dan saling membantu, yang dibayarkan bila peserta meninggal dunia, atau perjanjian telah berakhir (jika ada surplus dana).

Sistem inilah sebagai implementasi akad takāfuli dan akad muḍārabah, sehingga asuransi syariah dapat terhindar dari unsur garar dan maisir. Selanjutnya kumpulan dana peserta ini diinvestasikan sesuai dengan syariah Islam. Tiap keuntungan dari hasil investasi, setelah dikurangi dengan beban asuransi (klaim dan premi reasuransi), akan dibagi menurut prinsip muḍārabah. Persentase pembagian muḍārabah dibuat dalam suatu perbandingan tetap berdasarkan perjanjian kerja sama antara perusahaan dan peserta.

Sedangkan dalam sistem pada produk non saving (tanpa tabungan), setiap premi yang dibayar oleh peserta, akan dimasukkan dalam rekening tabarru' perusahaan. Rekening tabarru' yaitu kumpulan dana yang telah diniatkan oleh peserta sebagai iuran dana kebajikan untuk tujuan saling menolong dan saling membantu, dan dibayarkan bila: (a) Peserta meninggal dunia; (b) Perjanjian telah berakhir (jika ada surplus dana).

Kumpulan dana peserta ini akan diinvestasikan sesuai syariah Islam. Keuntungan hasil investasi setelah dikurangi dengan beban asuransi (klaim dan premi reasuransi), akan dibagi antara peserta dan perusahaan menurut prinsip muḍārabah dalam suatu perbandingan tetap berdasarkan perjanjian kerja sama antara perusahaan (takāful) dan peserta.

Dengan demikian dapat disimpulkan bahwa mekanisme pengelolaan premi pada AJB Bumiputera 1912 Syariah Cabang Kudus telah sesuai dengan prosedur dan mekanisme pengelolaan dana pada produk dengan sistem 
saving (tabungan), di mana iuran premi yang disetorkan oleh peserta ke perusahaan dibagi menjadi premi tabarru', premi tabungan dan premi biaya.

\section{Kesimpulan}

Dari penjelasan di atas, dapat disimpulkan bahwa produk-produk pada AJB Bumiputera 1912 syariah cabang Kudus adalah termasuk produk yang ada unsur saving (tabungan), yaitu asuransi perorangan (Mitra Sakinah, Mitra Mabrur dan Mitra Iqra') maupun asuransi kumpulan.

Selain itu, dalam melaksanakan kegiatan harian AJB Bumiputera 1912 syariah cabang Kudus, premi yang masuk ke perusahaan dikelompokkan menjadi premi Tabarru' (dana kebajikan), Premi Tabungan dan Premi Biaya.

Dan terakhir, aplikasi akad tabarru' pada AJB Bumiputera 1912 Syariah Cabang Kudus sesuai dengan fatwa Dewan Syariah Nasional (DSN) Nomor 21/DSN-MUI/X/2001 tentang pedoman umum asuransi syariah dinyatakan bahwa akad tabarru' adalah semua bentuk akad yang dilakukan dengan tujuan kebajikan dan tolong-menolong, bukan semata untuk tujuan komersial.

\section{Daftar Pustaka}

Al-Zuhaily, Wahbah. 1409 H. Al-Fiqh al-Islāmiy wa Adillatuh. Mesir: Dār al-Fikr.

Ali, AM. Hasan. 2004. Asuransi dalam Perspektif Hukum Islam: Suatu Tinjauan Analisis Historis, Teoritis dan Praktis. Jakarta: Kencana. cet. ke-1.

Antonio, M. Syafi'i. 2001. Bank Syariah: dari Teori ke Praktek. Jakarta: Gema Insani Press.

Basri, Ikhwan Abidin. 2008. "Teori Akad dalam Fikih Muamalah", dalam http://www.tazkiaonline.com/, diakses tanggal 11 Maret 2008.

Basyir, Ahmad Azhar. 1993. "Asuransi Takaful Sebagai Suatu Alternatif”, makalah dalam Seminar Sehari Takaful, Asuransi Syariah, TEPATI di Jakarta.

Dewan Syariah Nasional (DSN) Majelis Ulama Indonesia (MUI). 2001. Fatwa Dewan Syariah Nasional No. 21/DSN-MUI/X/2001 tentang Pedoman Umum Asuransi Syariah. Jakarta. 
Faisal, Sanapiah. 2003. Format-Format Penelitian Sosial. Jakarta: RajaGrafindo Persada.

Haroen, Nasrun. 2000. Fiqih Mu'amalah. Jakarta: Media Pratama.

Iqbal, Muhaimin. 2005. Asuransi Umum Syariah dalam Praktik. Jakarta: Gema Insani Press. cet. ke-1.

Karim, Adiwarman Azwar. 2007. Bank Islam: Analisis Fiqih dan Keuangan. Jakarta: Rajagrafindo Persada.

Rambe, HA. Nawawi. 1994. Fiqh Islam. Jakarta: Duta Pahala.

Sudarsono, Heri. 2004. Bank dan Lembaga Keuangan Syariah: Deskripsi dan Ilustrasi. Yogyakarta: Ekonisia. cet. ke-2.

Sugiyono, Metode Penelitian Bisnis. 2004. Bandung: Alfabeta.

Sula, Muhammad Syakir. 2004. Asuransi Syariah (Life and General): Konsep dan Sistem Operasional. Jakarta: Gema Insani Press. cet. ke-1.

Teguh, Muhammad. 2005. Metodologi Penelitian Ekonomi: Teori dan Aplikasi. Jakarta: RajaGrafindo Persada.

http:// www.pojokasuransi .com, diakses tanggal 05 Maret 2008.

http://www.republika.co.id/koran_detail.asp?id=327164\&kat_id=400, diakses tanggal 17 Juni 2008.

http://www.tazkiaonline.com/, diakses tanggal 11 Maret 2008. 